\title{
How a professional development programme changes early grades teachers' literacy pedagogy
}

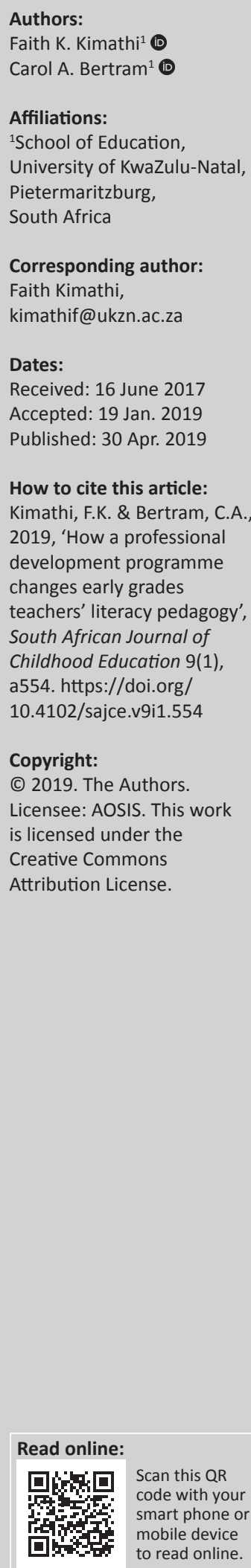

Background: Research on teacher professional learning which supports teaching of reading and writing at the foundation phase (FP) is limited in developing countries, including South Africa.

Aim: This article examines the ways in which three Foundation Phase teachers changed their practice during 18 months of learning from a formal university programme, the Advanced Certificate in Teaching (ACT).

Setting: The ACT was offered by the University of KwaZulu-Natal in South Africa.

Methods: The principles of teaching English as a First Additional Language (EFAL) were used as an instrument for describing change in practice. Using nine principles of teaching EFAL, derived from the ACT literacy learning guide as indicators, six video-recorded lessons (per teacher) were analysed and corroborated with interviews and field notes.

Results: The findings indicate a shift in teachers' practice in diverse ways. Two of the three teachers completed the programme having developed a deeper understanding of the natural approaches of acquiring EFAL according to Krashen's model. However, the third teacher did not change her practice.

Conclusion: We argue that the findings support the research claim that teacher learning is influenced not only by the nature of the professional development activity but also by teachers' personal motivation to learn, and the school context in which they teach.

Keywords: teacher learning; literacy practice; teacher change; foundation phase; South Africa.

\section{Introduction}

This article focuses on the impacts of professional learning of three selected foundation phase (FP) teachers who had enrolled on the Advanced Certificate in Teaching (ACT) programme in 2014/2015. The ACT programme was offered part-time to practicing FP teachers by the School of Education, University of KwaZulu-Natal, and 173 teachers were enrolled in 2014/2015. This article explores how the ACT programme influenced the teachers' classroom practices in teaching English as a First Additional Language (EFAL). Studies on how formal professional development (PD) impacts teachers' literacy knowledge for teaching reading and writing at the elementary level (FP in South Africa) is extensive in Australia and the United States (Carlisle, Cortina \& Katz 2011; Piasta et al. 2009). However, there is limited research in this field in South Africa and other developing countries (Brown, Wilmot \& Ash 2015; Meyer \& Abel 2015).

The issue of what teachers learn from PD programmes is not only a research concern but also a growing national concern as it impacts on the quality of the schooling system in South Africa. A great deal of state funds has been spent on upgrading teacher qualifications and increasing the PD activities for the teachers in the last three decades. However, findings on learner achievement indicate that PD seems to have little or no impact on learner achievement (Meyer \& Abel 2015; Murris \& Verbeek 2014; Taylor \& Taylor 2013). This may be because learning from formal PD programmes does not meaningfully contribute to the teachers' knowledge base, competences and/or practice (Green et al. 2011; Verbeek 2014). However, apart from classroom-based factors such as a weak knowledge base, the teachers' failure to organise effective practices (Hoadley 2013) and the sudden change to English as a medium of instruction in Grade 4 (Hoadley 2012; Prinsloo et al. 2015), there are other factors that contribute to the existing poor performance in schools, such as socio-economic issues like unemployment, poverty and malnutrition (Fleisch 2008) and the education legacy left by the apartheid regime (Spaull \& Hoadley 2017).

To describe the relationship that might exist between teacher learning from the ACT programme and change in teacher practice, this study explored how three Grade 2 teachers' learning from the 
ACT programme impacted on their practice of teaching EFAL. This study illuminates how three teachers' practice changed over 18 months, from when they enrolled on the programme in January 2014 to when they completed it in November 2015. Data from the video-recorded lessons corroborated with interviews and field notes which were analysed for insights. The implications of the findings contribute to our knowledge about PD for practicing teachers and how it impacts on the classroom practices at the FP (Grade R-3).

\section{Advanced Certificate in Teaching programme}

Since 2000, the Advanced Certificate in Education (ACE) and now the ACT programme has been offered to teachers who have a National Professional Diploma in Education (NPDE), as a way of deepening their knowledge base on the subjects they already teach, or to teachers who are specialising in a new content area or phase. This programme was perceived by the Department of Basic Education (DBE) as an opportunity for the teachers to improve their competences in teaching mathematics and literacy and obtain a higher qualification.

The ACT programme offered by the University of KwaZuluNatal (UKZN) School of Education consisted of eight modules with 16 credits per module. Each of the modules had a learning guide and student guide with a reading pack for self-study. The learning guide provided the content and learning activities. The student guide contained the structure of the programme and outlined the assessment requirements. These modules were systematically delivered over 2 years through mixed mode delivery, which included face-to-face teaching sessions on Saturdays and during school holidays, interactive materials and classroom-based assignments (Verbeek 2013). In semester 1, the students covered two modules: Module 1 was based on conceptual knowledge about child development; Module 2 was entitled Teaching and learning at the FP. Module 3 focused on mathematics content, whereas Module 4 related to teaching reading and writing in a home language (HL) in semester 2 in the first year of their study. Mathematics education in the foundation phase 1 is the title of Module 5 together with Module 6, and Teaching EFAL is covered in semester 1 of the second year. In semester 2 , the students study Module 7 Creative play in the FP and Module 8 Professional practice in the FP.

The main object of the programme was to deepen the teachers' content knowledge in mathematics and literacy and offer practical knowledge and skills for teaching at the early phase. The programme encouraged teachers' active contributions during the professional learning process, with the assumption that teachers would develop understanding of shifts in the FP curriculum and make use of frameworks of critical reasoning approaches to transform teaching and learning in their context (Hill \& Khuboni 2013). However, there has not been a great deal of systematic research to track the kind of literacy knowledge teachers' gain from formal PD programmes and their influence on practice (Brown et al. 2015; Meyer \& Abel 2015; van der Merwe \& Nel 2012). This article aims to contribute to this field.

\section{What does research say about teaching literacy at the foundation phase?}

Classroom practices during apartheid tended to emphasise technical decoding skills where teachers used oral and drilling discourses in the teaching of reading at the FP. Learners were able to decode text within simple English words, but did not understand what they were reading, mostly among the disadvantaged school contexts (Spaull \& Hoadley 2017). These dispositions were inherited in the post-apartheid era and are reflected in the current predominant literacy pedagogies. The first school curriculum in 1997 also did not provide a clear sequence for teaching phonics, reading and writing. Thus, many of the poorly trained FP teachers struggled not only with how to teach but also the implementation of Curriculum 2005. It is also well documented that many of the EFAL teachers in South African schools have limited English proficiency and have not been adequately trained in EFAL teaching methodologies (Green et al. 2011).

South African researchers have investigated the causes of continued poor performance in literacy and mathematics at the FP especially in the disadvantaged areas. According to the pre-PIRLS study of 2011, 58\% of learners in South Africa cannot read fluently or decode texts in either their HL or First Additional Language (FAL) by the end of Grade 4 (Spaull \& Hoadley 2017). Hoadley has conducted extensive literature reviews on the state of teaching and learning in the FP (Hoadley 2012, 2017; Spaull \& Hoadley 2017). These reviews consistently reveal 'communalised pedagogy that are largely oral, and that worked below grade level' (Hoadley 2016:16). The reviews correlate with the National Education Evaluation and Development Unit (NEEDU) reports and other studies (Prinsloo et al. 2015). All classroom-based studies present similar prevalent literacy pedagogies which include rote learning that denies learners' opportunities to participate during the lesson, ineffective use of repetition and grouping approaches, and the use of everyday knowledge with limited focus on conceptual understanding. Reading lessons consist of chorus chants with limited individual reading. Learners have few opportunities to engage with writing and vocabulary activities. The focus on reading has been on isolated words, rather than reading connected text not to mention the struggle most learners must endure when learning EFAL which is not their HL. According to the inter-province research study, most of the FP practices in the Gauteng and Limpopo provinces portrayed safe-talk tendencies. 'This means that both teachers and learners find comfort in keeping within the known content' (Prinsloo et al. 2015:XV). Such interactions would be interpreted as forms of inadequate teaching which lead to minimum learning opportunities.

However, Hoadley in one of the studies offers exemplars of what she calls 'good to moderate' classroom practices where higher levels of individualised learning are commonly characterised by 'ability grouping and a decrease in the collective chanting'. In some cases, 'teachers listen to individual learners reading, give more work at grade level 
[and] a greater proportion of text-based activity in classrooms and time on task had increased' (Hoadley 2017:16). She attributed these shifts to both the Foundations for Learning initiative and the Curriculum and Assessment Policy Statement (CAPS) which provides a clear structure for teachers to follow.

\section{Principles of First Additional Language supported by the school curriculum and Advanced Certificate in Teaching programme}

The current South African school curriculum, CAPS, explicitly adopts the notion of teaching four main content areas of literacy at the FP (Department of Basic Education 2011), namely: listening and speaking, reading and phonics; writing and handwriting in accordance with the emergent literacy. The conceptual knowledge about these core learning areas is privileged in the ACT-intended curriculum although the modules seem to engage more on the practical aspects of teaching (Christiansen, Bertram \& Mukeredzi 2018; Kimathi 2017). Thus, the ACT programme seems to promote diverse strategies of teaching the research-based components that are reinforced by the emergent literacy paradigm.

The current school curriculum employs additive bilingualism as a language acquisition approach to enhance multilingualism principles. In support of the approach, ACT Module 6 argues that children come to school with pre-literate behaviour which they acquire through interaction with older children, adults and everyday social routines which help them to develop necessary pre-literate knowledge, skills and attitudes. Therefore, children's literacy development should be nurtured formally in school using the HL of the learners and gradually introduce the additional language(s). The assumption here is that learners can automatically and progressively transfer many literacy skills from their HL literacy knowledge to learn EFAL and later use these languages for future learning. To nurture the children's literacy development process, the ACT modules emphasise the importance of networking with parents and teachers to find diverse ways to link children's knowledge from home with the school knowledge or literacy activities in school.

The school curriculum and ACT modules support the teaching of five components of reading, namely: phonemic awareness, phonics, fluency, vocabulary and comprehension (DBE 2011). However, the modules do not explicitly teach theoretical aspects on the components of reading. According to CAPS, specific times are set every day for reading and writing at the FP where learners are actively engaged with the content and subsequently writing activities as stipulated for each grade. The CAPS writing requirements to enable progressive literacy development among the young learners are: Grade 1 - writing short sentences, Grade 2 - writing paragraphs and Grade 3 - extended passages (DBE 2011). At Grade 2, the curriculum recommends that learners engage with writing activities four times a week, including one extended piece of writing (NEEDU 2013). However, teachers with inadequate knowledge may not be able to teach reading and writing to the standards set by the school curriculum. The challenge is even greater where the teachers have large classes with learners of mixed abilities, limited resources and support (Ebrahim, Verbeek \& Mashiya 2011; Hoadley 2016).

The ACT literacy modules encourage teachers to use both a formal approach and meaningful teaching activities such as rigorous simple spoken English and reading stories to enhance learners' EFAL competence. Teaching grammatically correct sentences and correct language use is viewed as key to effecting EFAL teaching. Similarly, CAPS support integration of the traditional approaches and Krashen's natural approach to acquisition of EFAL. According to the natural approach, it is not necessary to teach language structures or strict grammar rules to the learners of EFAL at FP. Learners of EFAL might learn sufficiently to do a once-off exercise correctly, but they may not be able to retrieve it from their working memory (Krashen 2009).

Reading-teaching theory privileged in CAPS includes: phonics, whole language and balanced approaches together with specified reading strategies such as shared reading (including shared writing); group-guided reading and paired or independent reading to support the literacy development (DBE 2011).

The ACT literacy curriculum supports these reading techniques and encourages teachers to be aware of the past as well as the current debates. Teachers need to explore three approaches, because some learners do well with direct instruction of phonics elements, while others progress better when a teacher takes the 'whole words' approach in a natural setting and break them into syllables and phonemes (Hill \& Khuboni 2013). The balanced approach tries to reconcile the whole language and synthetic phonics approaches to early reading and writing. Although the module supports the phonics-based and whole language approaches in teaching how to read, more emphasis is put on balanced approaches. However, according to several studies, many FP teachers have not been adequately trained to use these approaches (Murris \& Verbeek 2014). Overall, the ACT programme's literacy content supports the principles in the school curriculum, namely emergent literacy, language acquisition approaches, reading components, reading approaches and strategies.

\section{The methodology of the study}

The research approach is a case study of professional learning from the ACT programme and how the process contributes to practice changes. The qualitative case study researchers' focal objective is to generate rich, in-depth descriptions and analysis, which is only feasible with a small sample (Bassey 1999; Yin 2009). Thus, convenience and purposive sampling were used to select three Grade 2 teachers from the large group of FP teachers who had enrolled on the ACT programme in the 2014/2015 course period. Data were generated in three phases, namely at the beginning, middle and end of the 2-year ACT programme. Data were generated 
from selected EFAL video-recorded lessons corroborated with field notes. Six lessons were observed per teacher over the period of 18 months and were analysed using the nine principles of teaching FAL derived from the ACT Module 6 Learning Guide: Teaching English as an additional language in the FP.

Three black African female teachers participated in this study. Anne and Lisa completed their Matric in the 1990s. All three studied the NPDE qualification on a part-time basis at UKZN. Anne was in her late 40s with 15 years of experience as an FP teacher. She taught Grade R for 13 years and from 2013 has taught Grade 2. Anne had 44 learners in her class in 2014 and 36 in 2015. Anne claimed to have attended two PD workshops about teaching literacy in 2011-2013. Her school (school 1) is an urban school with moderate resources and facilities within a low-income residential area, located approximately $8 \mathrm{~km}$ from the Pietermaritzburg Central Business District (CBD), in the uMgungundlovu municipality. This is a quintile 4 school and parents pay fees of R1200.The language of learning and teaching (LoLT) in school 1 is English although almost all of the learners speak isiZulu as their HL.

Lisa was in her mid-forties teaching in a township school with 13 years of experience as an FP teacher in school 2. Lisa started as a Grade 3 teacher and taught at this level for 10 years before joining Grade 2. Her class (in 2015) has 44 learners and the previous year (2014), there were 42 learners. After completing the NPDE, Lisa enrolled and completed the ACE Life Orientation certificate with the University of South Africa in 2010. Lisa claimed to have attended several training workshops (more than five times) about teaching literacy in 2011-2013. School 2 is a quintile 3 township school with adequate resources, $65 \mathrm{~km}$ from Pietermaritzburg. Parents pay R100.00 in fees annually and are encouraged to pack a snack for their children.

Jane is in her mid-fifties and has taught many grades within her long period of teaching. She seemed uncomfortable talking about her qualifications and schooling. Jane claimed to have attended one training workshop about teaching literacy in 2011. Her current 2015 Grade 2 class has 52 learners and 54 learners in the previous year, 2014. School 3 is a rural junior primary school (Grade R-3), $105 \mathrm{~km}$ away from Pietermaritzburg. Learners do not pay school fees and heavily depend on the school feeding programme for their daily meals. It is categorised as quintile 2 . The LoLT in schools 2 and 3 is isiZulu.

\section{Classroom data analysis using principles of teaching English as a First Additional Language}

The main goal of this study was to establish what the three teachers learnt about teaching EFAL from the ACT programme and how this learning impacted on their practice. Observed lessons were analysed to explore any kind of shift in their classroom practices. To measure these changes, a set of principles of teaching FAL espoused in Module 6 was adopted and generated a set of concepts and indicators to describe teacher's change in practice.
The principles of teaching FAL formed an appropriate lens for several reasons. Firstly, the principles are specifically endorsed in three modules: Module 4 (teaching, reading and writing in HL), Module 6 (teaching EFAL) and Module 7 (creative play in the FP) as theories and conceptual knowledge which teachers should acquire from the ACT programme to enable effective teaching of literacy. Secondly, these principles of teaching EFAL are also endorsed by CAPS to enhance literacy teaching at the FP. Thirdly, English is offered as FAL in the three schools and used as LoLT in one of the schools. Lastly, these principles are in line with the global emergent literacy principles and literature (Moats 2014; Piasta et al. 2009)

We summarised the major principles of teaching EFAL in Module 6 (pp. 1-24) and then created a set of indicators to look for in the classroom data. The five major FAL principles were elaborated into nine indicators or aspects of the principles numbered as $1 \mathrm{~A}, 1 \mathrm{~B}, 2 \mathrm{~A}, 2 \mathrm{~B}, 3 \mathrm{~A}, 3 \mathrm{~B}, 4 \mathrm{~A}, 4 \mathrm{~B}$ and 5.0 in column 2 of Table 1.

As a first step to analysis, I (first author) organised and generated a description of each of the 18 video transcripts (six video-recorded lessons $\times$ three teachers) organised into episodes. To analyse the video transcripts, the second step was to develop a set of criteria and indicators to 'speak' to the classroom data devised from the nine descriptions of the principles of teaching EFAL (see Table 1). Astrong presentation of any of the aspects of teaching EFAL in the lesson was coded as 4 , while a very weak presentation of the principle was coded as 1 . The indicators of the aspects of the principles of teaching English as FAL were numbered from 1A to 5.0 in Table 1. An exemplar for the bilingualism principle numbered $1 \mathrm{~A}$ and $1 \mathrm{~B}$ is presented as a sample used in Table 2.

The third step of this analysis involved a careful reading of each episode of the 18 lesson descriptions several times, searching for statements which correlated with the principles of teaching EFAL (see Tables 1 and 2). For instance, using Table 2, a lesson episode was coded 1, 2, 3 or 4, for the principles of bilingualism (in both sub-categories coded as $1 \mathrm{~A}$ and $1 \mathrm{~B})$. The sub-category of the principles of teaching EFAL was vital to increase the accuracy level, as much as possible. Lastly, tables (see Tables 3, 4 and 5) were created for each of the six lessons per teacher which present a rich summative description of the classroom data analysis, for each to illustrate how the teachers' literacy pedagogies changed within the 18 months of learning. This kind of analysis creates a rich, in-depth description of specific aspects of the classrooms where the teacher, learners, resources, tasks, incidences and the subject knowledge are clearly understood (Ensor \& Hoadley 2004).

\section{The findings of this study}

The findings presented in this section illuminate the pedagogic changes for the three teachers. Detailed descriptions of the three teachers are offered under the methodology section. The findings reflect the analysis using the principles of teaching EFAL as offered in the 
TABLE 1: Principles of teaching English as a First Additional Language advocated in Module 6.

\section{Principles of teaching EFAL}

1.0. Bilingualism

Description of the principles

(1)

2.0. Theories of FAL that impacts teaching

2A. Formal learning of FAL

2B. Natural approach:

acquisition of FAL based on

Krashen's five hypotheses 3.0. Developing vocabulary and
oral sentences fluency

3A. Develop listening and speaking skills

3B. Building vocabulary in FAL

4.0. Balanced strategies that support the three approaches to literacy teaching

4A. Strategies and routines that support meaningful word study and reading

4B. Strategies and routines to enrich writing

5.0. Learning environment

5.0. Print-rich learning environment

\section{Indicators of 'good practice' in relation to Module 6}

L Teachers use code-switching to enhance meaningful communication to foster bilingualism. Learners are encouraged to use code-switching.

Learning EFAL should be enjoyable and pleasant. Repeated use of new knowledge in practice so that it becomes part of a child's working memory and is meaningful. Praise learners when they communicate in English.

Grammar-translation model - teaching of grammatically correct structures of English and isizulu in a conscious and formal manner.

- Teacher to provide opportunities which are context-based, informal and loosely organised for the learners to acquire FAL unconsciously.

- Children acquire FAL in a natural and a gradual orderly manner

- Monitor learners to use the FAL structure to correct their own errors, for example, during reading or storytelling is vital to acquire FAL.

- Consistent input from the teacher, interesting and relevant learning increases reading competence. - Teachers' moods, feelings and values affect the learners' acquisition of FAL.

Enhance purposeful listening and authentic speaking through verbal and non-verbal communication, for example, reading stories, use body language, imaginative role play, pictures, puppets and so on

Formal learning of vocabulary through labelling of classroom artefacts, direct instruction, actions and theme teaching. Learners learning to read for pleasure use vocabulary from their context and media. Use meaningful repetition, games and wide reading to support vocabulary building.

Word study - provide children with opportunities and routines to manipulate words in a meaningful way, for example, use of multiple assessment tools and sight words (word wall or word cards), fun activities and games. Word identification - provide opportunities to practice and identify word.

Word identification - provide opportunities to practice and identify word.
Use both phonic approaches and whole word approaches to teach reading. Games or songs or exercises to Use both phonic approaches and whole word approaches to teach
strengthen the letter-sound relationship (vocabulary building).

Model good handwriting to the learners; pay attention to their scribbles and drawings; teach handwriting; provide opportunities where they can write words and letters to enable sentence building.

Create and make use of a print-rich learning environment to meet learners' specific needs, for example, adequate children's literature that is accessible to all, teachers' artworks and learners' creative work displays, sight words, phonic charts and posters of themes. Reading or discussion corner or a classroom library which is accessible.

Source: Kimathi, F.K., 2017, 'Professional learning of Foundation Phase teachers in the Advanced Certificate in Teaching (ACT) programme', PhD thesis, School of Education, University of KwaZuluNatal. p. 141.

HL, home language; FAL, First Additional Language; EFAL, English as a First Additional Language.

TABLE 2: A sample of criteria used for coding the lessons.

\begin{tabular}{|c|c|c|c|c|}
\hline Aspects of bilingualism & 4. Strong presentation & 3. Moderate presentation & 2. Weak presentation & 1. Very weak presentation \\
\hline $\begin{array}{l}\text { 1A. Both HL and FAL must be } \\
\text { fully developed and used during } \\
\text { the lesson }\end{array}$ & $\begin{array}{l}\text { A balanced and appropriate use of } \\
\text { HL and FAL. Different approaches to } \\
\text { acquire EFAL skills. Teachers and } \\
\text { learners were often encouraged to } \\
\text { code switch }\end{array}$ & $\begin{array}{l}\text { The teacher code-switched } \\
\text { accurately and appropriately most } \\
\text { of the time. Adequate approaches } \\
\text { to acquire EFAL. Teachers and } \\
\text { learners were generally encouraged } \\
\text { to code switch }\end{array}$ & $\begin{array}{l}\text { Use of HL and FAL was not in } \\
\text { balance. Limited approaches to } \\
\text { acquire EFAL. Little code- } \\
\text { switching by both the teacher } \\
\text { and the learners }\end{array}$ & $\begin{array}{l}\text { Used HL or FAL only. Use of one } \\
\text { to two approaches to acquire } \\
\text { EFAL. } \\
\text { No code-switching was } \\
\text { presented }\end{array}$ \\
\hline $\begin{array}{l}\text { 1B. Receptiveness to acquiring } \\
\text { FAL }\end{array}$ & $\begin{array}{l}\text { Learners enjoyed the lesson and } \\
\text { were praised for all tasks. } \\
\text { Meaningful repetition and use of } \\
\text { new knowledge were applied } \\
\text { appropriately }\end{array}$ & $\begin{array}{l}\text { Learners enjoyed and were } \\
\text { regularly praised for completed } \\
\text { class tasks. Adequate repetition } \\
\text { and the use of new knowledge } \\
\text { were applied contextually }\end{array}$ & $\begin{array}{l}\text { Learners reasonably enjoyed and } \\
\text { were sometimes praised for } \\
\text { completed class tasks. Chants of } \\
\text { sentences, words and sounds } \\
\text { were sometimes used, with little } \\
\text { contextual application }\end{array}$ & $\begin{array}{l}\text { Children did not appear to enjoy } \\
\text { the lesson and were not praised } \\
\text { for the class tasks. Chants of } \\
\text { sentences, words and sounds } \\
\text { were common }\end{array}$ \\
\hline
\end{tabular}

Source: Kimathi, F.K., 2017, 'Professional learning of Foundation Phase teachers in the Advanced Certificate in Teaching (ACT) programme', PhD thesis, School of Education, University of KwaZuluNatal. p. 151.

Note: Criteria based on question: To what extent does the lesson portray the principle of bilingualism?

$\mathrm{HL}$, home language; FAL, First Additional Language; EFAL, English as a First Additional Language.

TABLE 3: The extent to which Anne's practice reflects the principles of teaching English as a First Additional Language. Criteria used for coding the FAL principles (Module 6)

Period of classroom video recording

\begin{tabular}{|c|c|c|c|c|c|c|}
\hline & \multirow{2}{*}{\multicolumn{2}{|c|}{ February 2014}} & & & & \\
\hline & & & \multicolumn{2}{|c|}{ August 2014} & \multicolumn{2}{|c|}{ October 2015} \\
\hline & $\mathbf{L 1}$ & $\mathbf{L 2}$ & L3 & L4 & $\mathbf{L 5}$ & L6 \\
\hline 1A: Development of bilingualism & 2 & 2 & 2 & 2 & 2 & 2 \\
\hline 2A: Formal approaches of learning FAL & 4 & 3 & 3 & 4 & 3 & 3 \\
\hline 2B: Natural approaches to acquiring FAL & 3.5 & 3 & 4 & 4 & 3 & 3 \\
\hline 3A: Development of listening and speaking skills & 3 & 3 & 3 & 4 & 3 & 3 \\
\hline 4A: Strategies to support reading and word study & 3 & 4 & 3 & 4 & 4 & 3 \\
\hline 4B: Strategies to support meaningful writing & 2 & 3 & 3 & 3 & 2 & 3 \\
\hline 5: Print-rich environment & 3 & 3 & 4 & 4 & 4 & 4 \\
\hline Total scores & 27 & 27 & 28.5 & 32 & 27 & 27 \\
\hline
\end{tabular}

Source: Kimathi, F.K., 2017, 'Professional learning of Foundation Phase teachers in the Advanced Certificate in Teaching (ACT) programme', PhD thesis, School of Education, University of KwaZuluNatal. p. 154.

Rubric used: $4=(4 \times 9=36)$ strong presentation or score; $1=(1 \times 9=9)$ very weak presentation or score.

FAL, First Additional Language. 
TABLE 4: The extent to which Lisa's practice reflects the principles of teaching English as a First Additional Language. Criterion used for coding the FAL concepts

\begin{tabular}{|c|c|c|c|c|c|}
\hline \multicolumn{6}{|c|}{ Period of classroom video recording } \\
\hline \multicolumn{2}{|c|}{ February 2014} & \multicolumn{2}{|c|}{ August 2014} & \multicolumn{2}{|c|}{ October 2015} \\
\hline L1 & L2 & L3 & L4 & $\mathbf{L 5}$ & L6 \\
\hline 3 & 3 & 4 & 3 & 3 & 4 \\
\hline 3.5 & 2 & 3 & 3 & 4 & 4 \\
\hline 3 & 2 & 4 & 3 & 4 & 4 \\
\hline 2 & 2 & 4 & 3 & 4 & 4 \\
\hline 2 & 2 & 3 & 3 & 4 & 3 \\
\hline 3.5 & 2 & 3 & 2 & 4 & 3 \\
\hline 2 & 2 & 3 & 3 & 2 & 4 \\
\hline 2 & 3 & 3 & 2 & 3 & 2 \\
\hline 2 & 2 & 3 & 3 & 4 & 4 \\
\hline 23 & 20 & 30 & 26 & 33 & 32 \\
\hline
\end{tabular}

1A: Development of bilingualism

1B: Receptivity to acquiring FAL

2A: Formal approaches of learning FAL

2B: Natural approaches of acquiring FAL

3A: Development of listening and speaking skills

3B: Building vocabulary in FAL

4A: Opportunities or strategies to support reading and word study

4B: Opportunities or strategies to support meaningful writing

5: Print-rich environment

Total scores

30

Source: Kimathi, F.K., 2017, 'Professional learning of Foundation Phase teachers in the Advanced Certificate in Teaching (ACT) programme', PhD thesis, School of Education, University of KwaZuluNatal. p. 166.

Rubric used: $1=(4 \times 9=36)$ strong presentation or score; $4=(1 \times 9=9)$ very weak presentation or score.

FAL, First Additional Language.

TABLE 5: The extent to which Jane's practice reflects the principles of teaching English as a First Additional Language. Criterion used for coding the FAL concepts

\begin{tabular}{|c|c|c|c|c|c|}
\hline \multicolumn{6}{|c|}{ Period of classroom video recording } \\
\hline \multicolumn{2}{|c|}{ February 2014} & \multicolumn{2}{|c|}{ August 2014} & \multicolumn{2}{|c|}{ October 2015} \\
\hline L1 & L2 & L3 & L4 & L5 & L6 \\
\hline 2 & 2 & 3 & 3 & 3 & 3 \\
\hline 2 & 2 & 3 & 2 & 3 & 2 \\
\hline 3.5 & 3 & 3 & 2 & 2 & 2 \\
\hline 2 & 2 & 3 & 2 & 3 & 2 \\
\hline 2 & 2 & 2 & 2 & 3 & 3 \\
\hline 2 & 3 & 3 & 2 & 2 & 2 \\
\hline 2 & 3 & 2 & 2 & 2 & 1 \\
\hline 2 & 2 & 2 & 2 & 1 & 1 \\
\hline 2 & 2 & 2 & 2 & 2 & 2 \\
\hline 19 & 21 & 23 & 19 & 20 & 18 \\
\hline
\end{tabular}

1A: Development of bilingualism

1B: Receptivity to acquiring FAL

2A: Formal approaches to learning FAL

2B: Natural approaches to acquiring FAL

3A: Development of listening and speaking skills

3B: Building vocabulary in FAL

4A: Opportunities or strategies to support reading and word study

4B: Opportunities or strategies to support meaningful writing

5: Print-rich environment

Total scores

21

$23 \quad 19$

Source: Kimathi, F.K., 2017, 'Professional learning of Foundation Phase teachers in the Advanced Certificate in Teaching (ACT) programme', PhD thesis, School of Education, University of KwaZuluNatal. p. 175.

FAL, First Additional Language.

Rubric used: $1=(4 \times 9=36)$ Strong presentation or score, $4=(1 \times 9=9)$ very weak presentation or score.

ACT programme. Therefore, the article does not include an account of all principles of teaching EFAL or any other second language. This article does not allow for a detailed engagement of how these codes were arrived at; see Kimathi (2017) for a detailed analysis and findings. Firstly, we describe how Anne's pedagogic practices changed during her learning process in relation to the ACT-intended curriculum.

\section{Findings on Teacher Anne's English as First Additional Language pedagogic practices in school 1}

In February 2014, Anne enrolled for the ACT programme with the notion that the teachers' role in an ideal EFAL is to facilitate and monitor the progress of every learner, which is based on her experiences. Teaching in an urban school as described in the methodology section, Anne claimed that the teacher's core duty 'is to make sure the primary resources such as textbooks, chalk board and appropriate learning activities are available for a good lesson ... and the learners must respect, listen and respond' (Anne, teacher, female) to instructions given. This personal belief was confirmed by the well-sequenced teacher-centred lessons which were observed on two consecutive days in February 2014.

Table 3 presents a summary of how Anne's classroom practices changed during the professional learning process from the ACT programme.
In Table 3 the first column shows the nine aspects derived from the principles of teaching EFAL with the columns L1 (Lesson 1) to L6 (Lesson 6) showing the codes of the observed lessons. According to the criteria used, the possible total score was $4 \times 9=36$ for a lesson, where a score of 36 was 'ideal' and a score of 9 was recognised as weak presentation of all criteria. Column L4 shows the EFAL lesson with the highest score, while 1A on Development of bilingualism represents the aspect which scored very low. Lastly, 5 on 'Print rich environment' shows that the criterion of print-rich environment scored highly in all the lessons.

\section{Anne's practice at the beginning of the Advanced Certificate in Teaching programme (February 2014)}

At the beginning of professional learning in 2014, the two lessons that were observed illuminated a moderate presentation in relation to receptivity to acquiring FAL, explicit use of natural approaches to acquiring FAL and provided moderate opportunities or strategies for children to build new vocabulary, supported meaningful reading, writing and a print-rich classroom environment. Thus, Anne was already teaching according to many of the principles of EFAL. She started both lessons in the same systematic manner: peer-guided reading (2 minutes) an ice breaking activity (2 min), followed guided 'Big book' reading, phonics, 
spelling, and lastly, the learners' activity or homework. When asked about this sequencing of the lessons during the last interview in October 2015, Anne replied, 'it is recommended [by CAPS] and I think it is a good one'. (Anne, teacher, female) She used isiZulu occasionally to explain confusing concepts to the learners. The learners were fluent in English and authentic communication in English was evidenced during the teachers' talks in all episodes. Occasionally, a few learners repeated guided reading or words depicting little comprehension significant of the story, verbs or prepositions. Children were free to talk and were praised occasionally but the teacher seemed disappointed with learners' misconceptions. Anne accurately and systematically read and explained each sentence before proceeding to the next. Individual errors were corrected in the whole class and the text was at the level of the learners. Reading from the big book, the teacher engaged the learners into a conversion through the questioning technique but did not make use of the displayed prints. She scored 2 in three aspects: the development of bilingualism (both lessons), strategies of developing listening and speaking skills (lesson 1) and opportunities or strategies used to develop meaningful writing (lesson 1). These three principles of FAL were not strongly present in her practice when she enrolled for the ACT programme.

\section{During the Advanced Certificate in Teaching programme (August 2014)}

During the professional learning process, the two videorecorded lessons in August 2014 show a slight shift in most of the FAL principles. Apart from developing bilingualism which remained weak (score of 2), all other areas of presentation were mainly at moderate and strong levels. The total score for lesson 3 was 26.5 for the nine principles coded, whereas lesson 4 presented the score of 32 in all the principles, as shown in Table 3. The teacher selected and sequenced the content in a systematic manner, focusing on the vocabulary and sentence constructions using adjectives. The learners were actively involved and happy as individuals answered the teacher's questions and pasted the correct adjective using the sight words. Most of the learners applied their prior knowledge with ease and engaged with the teacher during the different episodes. The majority of the learners completed copying sentences on time. The teacher encouraged them and was very patient with the slow learners and applauded every correct response. Generally, the exercise of identifying an adjective and constructing a sentence orally seemed easy for most of the learners.

\section{At the end of the Advanced Certificate in Teaching programme (October 2015)}

By October 2015, the teachers had covered the entire ACTintended curriculum (eight modules). Lessons 5 and 6 show an insignificant change (score dropped by 5), in relation to the previous lesson observation in February 2014 and August 2015. However, moderate presentations of the FAL principles were observed, apart from the development of bilingualism and the strategies used to support meaningful reading and writing. There was a clear indication that Anne's practices made a slight shift in terms of using the resources displayed because she already had a large quantity of displays in almost every free space in the class. For example, learners who finished their activities were supposed to pick reading books from the reading corner, giving the teacher an opportunity to monitor the task, and mark or help the struggling learners. The teacher also made references to the posters or the learners' work that was distinctive from the classroom observations in February 2014. With regard to the development of bilingualism, this did not show any change over the 18 months. Anne did not use the code-switching technique during the first observation, nor did she do so at the end of the ACT programme. Anne's focus on developing English proficiency was at the expense of the learners' HL, isiZulu. This is attributed to the fact that the LoLT in school 1 is English, and thus, Anne's practice reflects the school policy, which was to emphasise the use of English at the expense of isiZulu, because English is the LoLT from Grade 1.

\section{Findings on Lisa's English as First Additional Language pedagogic practices in school 2}

Table 4 presents a summary of the findings on how Lisa's classroom practices changed during learning from the professional programme.

Table 4 shows that many of the principles started with a weak presentation in February 2014 and showed a change in practice by end of the programme with the most improved aspects at $1 \mathrm{~B}, 2 \mathrm{~A}$ and $2 \mathrm{~B}$. Lesson 5 (L5) presents the highest overall score of 33 . Rows $3 \mathrm{~B}$ on 'building vocabulary' and $4 \mathrm{~B}$ on 'opportunities to support meaningful writing' highlight an unpredictable presentation of both principles across the six lessons. Lisa showed the most significant change in practice of the three teachers.

\section{Lisa's practice at the beginning of the Advanced Certificate in Teaching programme (February 2014)}

At the beginning of her professional learning on the ACT programme, Lisa started the observed lesson by writing the letter $s$ and $t$ on a mini board and explained how the two sounds combine to form a new sound st. She was fluent in English but used isiZulu language as LoLT. Learners wrote the sound $s, t$ and $s t$ on their mini boards and flashed the boards up for the teacher. It seemed that the learners were familiar with the activity and the teacher praised the class for the well-done work. The teacher read the sentences on the chalkboard and focused on the phonic aspects which the learners repeated several times. The learners copied the sentences in their exercise books as the teachers monitored their work. The learners' interaction with the teacher and their peers was in isiZulu. Feedback in English was limited to the chanting of single words or answering low-order questions with a 'yes' or 'no'. Lisa did not give the children time to manipulate the words in a meaningful manner to establish patterns in the words nor did she use the written resources which were available in class. The two lessons provided limited writing for the learners. According to the EFAL principles, Lisa scored a moderate representation of 23 and 20 for two observed lessons for lessons with an average 
score of 2 in almost all the principles (Table 4). This means that most of the principles of EFAL were not strongly present in her practice when she enrolled for the ACT programme.

\section{During the Advanced Certificate in Teaching programme (August 2014)}

The observed lessons in August 2015 indicated a great shift of practices as she improved in all the principles. Lesson 3 was practical, and the teacher distributed mini boards, chalks, small dusters and a set of cards to each child. She introduced the lesson in English and repeated this in isiZulu to explicitly explain the phonics. Lisa engaged with the CAPS work-books during lesson 4 but in both cases at oral level which consisted of simple questions and chants of the words using the daily knowledge discourses. Lisa still scored a weak representation on two principles during lesson 4. She did not offer learners any opportunity to support writing and did not explicitly build vocabulary. According to CAPS, writing in EFAL should receive more focussed support at Grade 2, and learners are expected to write a simple set of instructions and a personal recount (DBE 2011).

\section{At the end of the Advanced Certificate in Teaching programme (October 2015)}

By October 2015, Lisa showed an impressive improvement in most of the EFAL practices. She scored highly, with strong and moderate representations in most of the principles (Table 4). Lesson 5 was different, and learners were settled down when Lisa surprisingly uncovered a self-drawn picture of a child playing at a local beach (Durban) mounted on the wooden stand. This created suspense and joy among the children. Lisa engaged the learners which stimulated a classroom conversation. The next episodes were more interactive with writing and drawing opportunities created using a more detailed and colourful poster about leisure activities of a typical coastal resort. The posters and displays in the classroom had gradually changed to a stronger printrich environment from the previous observations. Learners were able to learn letter sounds and use phonic resources which were piled in the classroom during lesson 6 . However, there were still minimum opportunities to engage learners with writing and print reading during this lesson.

These data suggest that Lisa presented practices of an FP teacher who acquired new knowledge and skills in most aspects from the ACT programme and was able to apply these skills in her classroom. This implies that during her enrolment on the ACT, Lisa changed her classroom practices according to some of the FAL principles.

\section{Findings on Jane's English as First Additional Language pedagogies practice in School 3}

Lastly, we present findings of Jane's six analysed EFAL lessons in Table 5:

Overall, Table 5 shows that there was very little change in Jane's practice over the 18 months. Jane's lesson 3 (L3) indicates the best lesson observed. The development of bilingualism (1A) shows an improvement across the
18 months. However, there was no improvement in the printrich environment (5), nor in strategies to support meaningful writing and reading (4A and $4 \mathrm{~B})$.

\section{Jane's practice at the beginning of the Advanced Certificate in Teaching programme (February 2014)}

In the first lesson observed, Jane read a story and predominately used isiZulu to explain the English words and sentences. She seemed uncomfortable when speaking in English. Learners' interaction with the teacher and their peers was mostly in isiZulu. The teacher used simple questions, like 'what are you doing' most of the time and concentrated only on positive responses from a few active learners, whereas most learners seemed not to follow the lesson. Feedback in English was only a single-word answer or repeating what the teacher said. Choral reading and repeating sentences with little understanding or contextual application prevailed. The instructions given for the writing task were not explicit; thus, learners did not construct new sentences as the teacher expected. The dusty walls had a few old posters and charts from the DBE for isiZulu and English phonics, life orientation charts on hygiene and health, and numeracy charts on additions, subtraction and numbers. Learner's work books and a few textbooks were locked in a cupboard and only accessible to the teacher.

So, at the beginning of the professional learning with the ACT programme, Jane's lessons in relation to the nine FAL principles observed in February 2014 scored a total of 19 and 21 in the first and second lessons. The two lessons observed illuminate a weak presentation in almost all the principles of teaching English as FAL, with an exception of moderate presentation on formal approaches to learning FAL (both lessons), building vocabulary in FAL (lesson 2) and on opportunities or strategies offered to support reading and word study (lesson 2). This implies that prior to enrolling for the ACT programme, Jane's teaching practices were not in accordance with the principles of teaching FAL, as stipulated in Module 6. This correlates with a great deal of the South African empirical findings, which indicate that most of the FP teachers in the rural areas have limited teacher knowledge to enable efficient teaching of literacy and mathematics (Green et al. 2011).

\section{During the Advanced Certificate in Teaching programme (August 2014)}

After the first semester of the ACT, Jane's classroom practices observed in August 2015 present a similar pattern of weak presentations in relation to the FAL principles observed in February 2014. The marginal score was a weak presentation in almost all the principles and very weak in lesson 4 on the opportunities or strategies used to support meaningful writing, implying that there was no change of classroom practices even after learning on the ACT programme for one semester. Her total score was 23 (lesson 3) and 18 (lesson 4), as compared to 19 (lesson1) and 21 (lesson 2) in February 2014 when she started learning the programme. 


\section{At the end of the Advanced Certificate in Teaching programme (October 2015)}

A similar representation was observed for Jane's scores at the end of the programme, with moderate presentation of most principles and a very weak score for opportunities offered to support meaningful writing. Opportunities and strategies to support reading and word study were also poorly presented in lesson 6 and, thus, coded as a very weak presentation. With regard to a print-rich classroom environment, there is a clear indication that this remained the same during the 18 months. She did not change or use prints on the class walls in an effort to promote a print-rich learning environment. Although she claimed to have improved the quality and quantities of the classroom display over time during the August 2015 interview session, poster and chart displays did not change. Overall, Jane seems to have made no significant changes in her classroom practices in relation to the nine principles of teaching FAL. She may have learnt some conceptual knowledge from the ACT programme, and may have understood the methodologies, but did not put them into practice during the 18 months.

\section{Ethical considerations}

The article originates from a broader study $(\mathrm{PhD})$ from data which explored professional learning of three Grade 2 teachers and how they changed their EFAL lessons during the time of enrolment with the ACT programme at UKZN in South Africa. Data collected over 18 months consisted of six classroom observations or videos, interviews and field notes (in February 2014, August 2014, October 2015). Participants consented to participate in the research by signing a consent form and permission was granted by the KwaZulu-Natal Department of Basic Education (Ref 1/102/2014). The UKZN Higher Degrees and Ethics Committee awarded the ethical clearance (Ref. HSS/0098/014D).

\section{Discussion of the findings}

The overall findings show that by the end of the programme in October 2015, the three FP teachers, although they completed the same course, changed their classroom practices in different ways. When Anne and Lisa completed the programme, they seemed to have developed a deeper understanding of EFAL teaching strategies according to the nine principles of teaching FAL and a shift in their practice in this regard. However, Jane seems not to have engaged with the principles of FAL teaching by the end of the programme. This does not necessarily mean that Jane did not acquire any conceptual knowledge from the ACT programme but seemed unable to use it in her practice.

Anne was already practicing many of the EFAL principles when she enrolled in the ACT programme, and thus she displayed only a slight shift in practice. Anne was a selfmotivated person with over 10 years' experience at school 1 . Her school charged an annual fee of R1300 with moderate teaching resources and infrastructure compared to school 2 and 3 contexts. In addition, parental choice of English as
LoLT means some of the children speak English at home and have access to other language learning opportunities apart from school. There was less for her to learn from the ACT programme, and thus her practice did not change that much.

Lisa was in the same career phase and age bracket as Anne. She seemed to be an enthusiastic learner with good conceptual understanding who showed a much stronger learning curve than Anne. She also had more professional learning opportunities from a non-governmental organisation called Soul City which supported the teaching of phonics with resources and classroom support in her school. This must have also made an impact to her classroom practices. Lisa made positive, consistent changes and displayed adequate principles of EFAL teaching within the period of their enrolment. In contrast, Jane was an older teacher, close to retirement, in a rural school environment and with limited English proficiency and subject knowledge. According to Day and Gu (2007), the teachers' career phase and personal identities influence their motivation for professional learning. Jane may have lacked self-motivation because she was near retirement age. Other underlying mechanisms which contributed to the minimal practice changes include contextual challenges such as inadequate learners' textbooks, teacher's guides and basic teaching resources and the fact that children have no other access to English apart from the school. The socio-economic context was poor, and the school entirely relied on DBE for learning resources, infrastructure, water supply and feeding programme. However, Jane claimed that the ACT programme had enabled her to gain confidence in teaching EFAL and proficiency in English. The struggles and challenges faced by Jane concur with other classroom-based studies and reviews of FP practices (Hoadley 2016; Prinsloo et al. 2015; Spaull \& Hoadley 2017).

These findings echo most of the small-scale studies about the differences in the teacher's take-up from PD activities and their impacts to the classroom discourses (Adler \& Reed 2000; Blease \& Condy 2014; Brown et al. 2015; Meyer \& Abel 2015). Professional learning is a complex process situated in practice, which cannot be separated from systems, structures, teachers' histories and school context (Battey \& Franke 2008; Opfer \& Pedder 2011). According to this socio-cultural insight, teachers' identities and contexts bring variation to what teachers' take-up from the professional activities and how they enact the new ideas in their classrooms.

\section{Concluding remarks}

Anne and Lisa benefitted most from the ACT programme. This may be because they taught in schools with more favourable conditions, and were more self-motivated, unlike Jane, who was close to retirement and teaching under more challenging conditions, where English is essentially a foreign language for both learners and teachers. The learning experiences of the three FP teachers suggest that a formal programme like the ACT will not necessarily bring about effective and sustainable improvements in teaching and learning for all teachers who enrol. Other factors such as 
the teachers' enthusiasm, career phase, the teachers' participation in other PD activities and the school context (both resourcing and collegial support for teacher learning) are crucial aspects that can support or hinder the teacher's professional learning from the formal programme.

\section{Acknowledgements}

This research has been developed through the University of KwaZulu-Natal's postdoctoral scholarship offered to F.K.K. and hosted by C.A.B. at UKZN, School of Education, Pietermaritzburg Campus.

\section{Competing interests}

The authors declare that they have no financial or personal relationships that may have inappropriately influenced them in writing this article.

\section{Authors contributions}

F.K.K. is the primary researcher who is reporting on her $\mathrm{PhD}$ study. She is the primary writer of the article. C.A.B. was the supervisor of the study and has contributed to the article by providing guidance regarding focus and structure.

\section{References}

Adler, J. \& Reed, Y., 2000, 'Researching teachers "take-up" from a formal in-service professional development programme', Journal of Education 25, 192-226.

Bassey, M., 1999, Case study research in educational settings, Open University Press, Philadelphia, PA.

Battey, D. \& Franke, M.L., 2008, 'Transforming identities: Understanding teachers across professional development and classroom practice', Teacher Education Quarterly 35, 127-149.

Blease, B. \& Condy, J., 2014, 'What challenges do foundation phase teachers experience when teaching writing in rural multigrade classes?', South African Journal of Childhood Education 4, 36-56.

Brown, B., Wilmot, D. \& Ash, M.P., 2015, 'Stories of change: The case of foundation phase teacher professional development programme', South African Journal of Childhood Education 5, 191-209. https://doi.org/10.4102/sajce.v5i1.356

Carlisle, F.J., Cortina, S.K. \& Katz, A.L., 2011, 'First-grade teachers' response to three models of professional development in reading', Reading \& Writing Quarterly: Overcoming Learning Difficulties 27, 212-238. https://doi.org/10.1080/10573569 .2011 .560482

Christiansen, I.M., Bertram, C. \& Mukeredzi, T., 2018, 'Contexts and concepts: Analysing learning tasks in a foundation phase teacher education programme in South Africa', Asia-Pacific Journal of Teacher Education 20, 1-17. https://doi.org/ 10.1080/1359866X.2018.1461804

Day, C. \& Gu, Q., 2007, 'Variations in the conditions for teachers' professional learning and development: Sustaining commitment and effectiveness over a career' Oxford Review of Education 33,423-443. https://doi.org/10.1080/03054 980701450746

Department of Basic Education (DBE), South Africa, 2011, Curriculum and Assessment Policy: First additional language for Grade 1-3, Foundation Phase, Government Printer, Pretoria.
Ebrahim, H.B., Verbeek, D.C. \& Mashiya, J.N., 2011, 'Enabling roles to reclaim teacher agency: Insights from the advanced certificate in teaching (Foundation Phase)', agency: Insights from the advanced
Perspectives in Education 29, 58-63.

Ensor, P. \& Hoadley, U., 2004, 'Developing languages of description to research pedagogy', Journal of Education 32, 81-104.

Fleisch, B., 2008, Primary education in crisis: Why South African schoolchildren underachieve in reading and mathematics, Juta \& Co, Ltd, Cape Town.

Green, W., Parker, D., Deacon, R. \& Hall, G., 2011, 'Foundation phase teacher education provision', South African Journal of Childhood Education 1, 109-121. https://doi.org/10.4102/sajce.v1i1.80

Hill, A. \& Khuboni, F., 2013, Advanced Certificate in Teaching (ACT) Foundation Phase. ACT 4 Learning Guide: Teaching reading and writing in home language in foundation phase, University of KwaZulu-Natal, School of Education, Pietermaritzburg Campus.

Hoadley, U., 2012, 'What do we know about teaching and learning in South African primary schools?', Education as Change 16, 187-202. https://doi.org/10.1080/16 primary schools?', Ed

Hoadley, U., 2013, 'Building strong foundations: Improving the quality of early education', South African Child Gauge 72-77.

Hoadley, U., 2016, A review of the research literature on teaching and learning in the Foundation Phase in South Africa', Research on Socioeconomic Policy (ReSEP), Working papers, 5/16.

Hoadley, U., 2017, 'Learning to fly: Pedagogy in the Foundation Phase in the context of the CAPS reform1', Journal of Education 67, 13-38.

Kimathi, F.K., 2017, 'Professional learning of Foundation Phase teachers in the Advanced Certificate in Teaching (ACT) programme', PhD thesis, School of Education, University of KwaZulu-Natal.

Krashen, S.D., 2009, Principles and practice in second language acquisition, Pergamon Press Inc, University of Southern California, Los Angeles

Meyer, S. \& Abel, L., 2015, 'Hastening slowly: Insights about teacher development from an evaluation of courses at the WCED's Cape Teaching and Leadership Institute', Journal of Education 61, 115-146.

Moats, L.C., 2014, 'What teachers don't know and why they aren't learning it: Addressing the need for content and pedagogy in teacher education', Australian Journal of Learning Difficulties 19, 75-91. https://doi.org/10.1080/19404158.201 4.941093

Murris, K. \& Verbeek, C., 2014, 'A foundation for foundation phase teacher education: Making wise educational judgements', South African Journal of Childhood Education 4, 1-17. https://doi.org/10.4102/sajce.v4i2.201

National Education Evaluation and Development Unit (NEEDU), 2013, South Africa National Report 2012: The state of literacy teaching and learning in the foundation phase, Government Printer, Pretoria.

Opfer, V.D. \& Pedder, D., 2011, 'Conceptualising teacher professional learning', Review of Educational Research 81, 376-407. https://doi.org/10.3102/0034654311413609

Piasta, S.B., Connor, C.M., Fishman, J. \& Morrison, F., 2009, 'Teachers' knowledge of literacy concepts, classroom practices and students reading growth', Scientific Studies of Reading 13, 224-248. https://doi.org/10.1080/10888430902851364

Prinsloo, C.H., Ramani, E., Joseph, M., Rogers, S., Mashatole, A., Lafon, M. et al., 2015 An inter-province study of language and literacy paradigms and practices in Foundation Phase classrooms in Limpopo and Gauteng, HSRC, Pretoria.

Spaull, N. \& Hoadley, U., 2017, 'Getting reading right', in L. Jamieson, L. Berry \& L. Lake (eds.), South African Child Gauge 2017, pp. 77-83, Children's Institute, University of Cape Town, Cape Town.

Taylor, N. \& Taylor, S., 2013, 'Teacher knowledge and professional habitus', in N. Taylor, S. van der berg \& T. Mabogoane (eds.), Creating effective schools, pp. 204-233, Liesbet van Wyk, Cape Town.

Van Der Merwe, Z. \& Nel, C., 2012, 'Reading literacy within a teacher preparation programme: What we know and what we should know', South African Journal of Childhood Education 2, 137-157. https://doi.org/10.4102/sajce.v2i2.16

Verbeek, C., 2013, Advanced Certificate in Teaching Foundation phase: ACT 1 Learning Guide: Child development in the early years, University of KwaZulu-Natal, School of Education, Pietermaritzburg Campus.

Verbeek, C., 2014, 'Critical reflections on the PGCE (Foundation Phase) qualification in South Africa', South African Journal of Childhood Education 4, 37-51. https://doi. org/10.4102/sajce.v4i3.225

Yin, R.K., 2009, Case study research, Sage, Los Angeles, CA. 